\title{
Local Militia as a Counterterrorism Strategy and Peacebuilding in the erstwhile FATA
}

\author{
* Dr. Rahman Ullah, BBC Broadcast Journalist / Visiting Faculty \\ ** Dr. Saeed Ahmed, Associate Professor
}

\begin{abstract}
The lashkars have a very long history in the erstwhile Federally Administered Tribal Areas (FATA) of Pakistan. These lashkars were usually constituted in a short span of time to respond quickly to any deteriorating law and order situation. The participants usually acted as volunteers to settle the disputes and soon dispersed. No doubt, this is the concept of the traditional lashkars that provided a basis for the raising of the peace lashkars. This was an announced or informal strategy of the government to counter militants in the tribal belt. However, some terms like Aman lahkar or Aman lashkar were locally used for the anti-Taliban militias to counter the Taliban in the former FATA. Though the peace lashkars never got any formal name but the government fully supported them by issuing them special permits to keep sophisticated, automatic weapons like AK-47 to combat the militants. The paper investigates the historical perspective behind the formation of the anti-Taliban militias. However, the paper mainly analyse the role of the Anti-Taliban militias in the counterinsurgency and peacebuilding in the erstwhile FATA.
\end{abstract}

Keywords: Anti-Taliban Militias, Peacebuilding, Insurgents, Counter-insurgency, Erstwhile FATA

\section{Introduction and Historical Background}

The history of the traditional lashkars of the tribal belt is very old. However, the formation of the peace lashkars are closely connected with the aftermath of the 9/11 terrorist attacks on the United States of America's twin towers viz World Trade Center (WTC) and Pentagon. The United States held the Al-Qaeda's chief Osama Bin Laden responsible for these attacks. The then Ameer-ulMomineen of Taliban Mullah Muhammad Omer declined the request of the US to hand it over the Saudi billionaire Osama Bin Laden who harboured in Afghanistan. The US invaded Afghanistan in October 2001 and toppled the Taliban rule. The Taliban infiltrated into the tribal areas of Pakistan. The Taliban, as an alternative force, tried to fill the gap in between the tribal people and the indifferent rulers in the tribal belt. However, this dream of the militants could hardly have been materialized in the presence of the influential tribal elders. The tribal elders worked as bridge in between the tribals and the administrators (known as Political Agents before May 2018) (Ashraf Ali, 2020). For multifarious reasons, the tribals were not happy with their leaders, some of the tribal leaders were deemed as more loyal to the government officials as compared to the locals. At the outset, the Taliban started the largescale targeted killings of the tribal elders, which served doubleinterests of the militants, removing of the tribal elders as the main obstacles and spreading horror in the tribal belt. A number of the tribal elders were forced to flee from their areas for personal and family safety. In the past, the routine land disputes, law and order situation were controlled by these tribal elders through traditional lashkars but the situation is totally different now (Ali, 2016). In the erstwhile FATA, the notion of the traditional militias spans over a period of hundred-long years. However, the government started informal support of the peace lashkar, Aman Lashkar in 2002. The Pakistani government needed the help of the local to combat the militants in the tribal belt. In 2008, the Pakistani government formally mobilized the local people in the erstwhile tribal viz Mohmand, Khyber and Bajaur agencies to raise peace militias ${ }^{I}$ (anti-Taliban lashkars) to combat the Taliban. In

${ }^{1}$ Lashkar is Pashto word used for a traditional and semi-permanent force of tribal volunteers that is raised by a tribe to punish the outlaws.

* Department of Political Science, University of Peshawar. Email: rahmanullah.khattak01@bbc.co.uk

** Government Degree College, Bakhshali. Email: saeed.sani81@gmail.com 
May 2018, the $25^{\text {th }}$ Constitutional amendment was passed by the Parliament of Pakistan, whereby the seven tribal agencies of FATA were merged in the province of Khyber Pakhtunkhwa. These seven agencies are now known as the tribal districts of the province. To gain the full cooperation of the tribals against the Taliban, the rulers, though never, officially declared the raising of the peace militias, but the military extended the tribals all-out help in forming the anti-Taliban lashkars (Clegg, 2009, p. 07).

The raising of private militas was infringement of the article 256 of the Constitution of the Islamic Republic of Pakistan. According to this article none is allowed to form private militias and only the regular forces or law enforcement agencies of the government are entitled to use arms. The article says: "Private armies forbidden. -- No private organisation capable of functioning as a military organisation shall be formed, and any such organisation shall be illegal"(Munir, 1999).

Arbaki is the homogenous term used for lashkars in the neighbouring Afghanistan. Though the Arbaki has been used as an alternate term for lashkars, yet both the terms have different connotations. Compared to Arbaki, the lashkars enjoy much prestige as a civilian force that are usually constituted as a riposte to cry or shout (Pashto Chagha) to counter the menace or foe and thus safeguard the area.

According to David J Francis, the word 'militia' is derived from the Latin miles, which miles is used for soldier. A private militia may be explained as a civilian army constituted of the volunteers aged from sixteen to sixty years to carry out only imperative actions to defend their country, colony or state (Francis, 2005, p. 1).

Prior to the partition of the sub-continent, with integrated struggles, the tribals raised a unified Lashkar to vanquish the hatched plot of the British commissioner John Cameron as he challenged the tribals. In 1906, the tribals formed the first formal tribal Lashkar, however, usually the following three situations ushered the raising of the militias in the tribal areas.

1) When government intervenes in the internal affairs of the tribals.

2) When the tribals felt that someone wants to use the tribal areas for their vested interest or goals.

3) When someone is killed for a land, the killer may belong to the same family or outside the family.

Lashkars were responsible for guarantying complete peace in the area. When a lashkar was not engaged in war, it held meetings on specified days. In the meetings, the lashkar carefully listened to tribal issues and resolved or referred them to the low-ranking or subordinate members concerned. Lashkars took all measures in a simple way and peaceful manner. The Lashkar leader was responsible to every member. Every member of a lashkar could disagree with the decision of the leader even if he had concrete arguments (Saboor, 1999).

As heading a lashkar was the most difficult task, thus the leader had to pass through a tough selection criterion. The given few points were part of the selection criterion set for choosing a lashkar chief:

1) Enough knowledge of Islamic laws;

2) No indulgence in corrupt practices or nepotism;

3) Full command of tribal laws and bravery;

The tribesmen have also raised militias to counter the British soldiers. The history has witnessed that the tribals formed such lashkars in 1937 and rose up against the British Army (Zahid, 2007). To control the tribals, the British had also used strict laws and para-military forces, both Khasadars and Frontier Scouts. Both are considered as the off-shoots of those informal or irregular British forces constituted by the government of British India. The Khasadar forces have been given the status of formal police after the FATA was merged in the Khyber Pakhtunkhwa (Clegg, 2009).

The Jirga was mainly responsible for the formation and dispersing of the traditional lashakrs in the past while the number of the volunteers of such lasharks were unspecific. The Jirga usually enforced its decisions through these tribal lashakars to help the government officials to control the security situations in the erstwhile FATA (Ali, 2020).

\section{Traditional Lashkars versus Anti-Taliban Militias}

Though, the notion of the traditional militias has given impetus to the foundation of the peace militias or anti-Taliban militias, but the genesis, structure, recruitment criteria and operations of both these 
militias are at different poles. The Jirga usually ordered the formation of the traditional lashakrs that were gathered within no time and were thus dispersed after resolving the disputes. The traditional lashakars worked on temporary basis and were disorganized both in composition and operations. Contrary to the traditional lashakrs, the anti-Taliban militias were semi-permanent, more organized in composition and operations. There was no proper recruitment policy for the volunteers of the traditional lashakars, however, strict recruiting policy was used for the anti-Taliban militias to avoid the entry of militants' supporters. The basic difference in the traditional Lashkar and peace Lashkar lies in the full support of the entire tribe to the traditional Lashkar. Alternatively, $10 \%$ per cent tribesmen backed peace Lashkar or the anti-Taliban militias (Arshad Mohmand, interview, 2020).

The traditional Lashkars were termed as Qameez ${ }^{2}$ Lashkar (tribal Lashkar) as the whole tribe backed these Lashkars. Contrary to that, a meagre number of the tribals, however, supported the antiTaliban militias. As part of the tribal culture, the tribesmen have hardly shown any scepticism or distrust on the raising of the traditional lashakrs, however, no doubt there were conflicting views about the constitution of the anti-Taliban militias (Saeedullah, interview, 2020).

In the tribal district Khyber, the well-off and opulent tribals were controlling the traditional Lashkars. The tribal elders who could feed, provide weapons and might afford some small amount could easily own a traditional lashkar of around fifty gunmen. Before 2002, when the government backed anti-Taliban militias were not constituted, the traditional Lashkars were much functional in the tribal belt (Wali Khan Afridi, interview, 2020).

The traditional militias have deep history in the Pakistani tribal belt. The tribals have constituted the traditional Lashkars to punish the bandits, criminals, murders and all those who were challenging the law. The criminals and the abettors' houses were torched alike to set examples for others and thus to control law and order situation in the area (Malik Yousaf, interview, 2020).

\section{Militias' Composition and Operations}

\section{Tribal District Mohmand}

Bordered with Afghanistan, on November 26, 2011, this tribal district caught headlines in both national and foreign media when the NATO helicopters bombed a Pakistani checkpost here. Getting its name after the Mohmand tribe, the Mohmand agency was set up in 1951. The government of Pakistan ordered suspension of supply to the NATO forces in Afghanistan when 24 Security me lost lives in the NATO bombing here in a check post. The Government of Pakistan persuaded the tribesmen to form the Anti-Taliban militias mainly in three Tehsils of the Mohmand agency viz Tehsil Safi, Tehsil Baizai and Tehsil Khwaizai.

\section{Tribal District Khyber}

Bordered with Afghanistan, the tribal district Khyber was an important and historical tribal agency in the erstwhile FATA of Pakistan. This tribal district is named after the reputed Khyber Pass. This tribal district has great importance because a huge portion of trade in between Pakistan and Afghanistan occurs via Torkham gateway. Likewise, Torkham gateway is also used for a largescale of supply to the NATO troops stationed in Afghanistan.

\section{Tauheed-ul-Islam in Zakhakhel}

Hakim Khan was the chief of the political affairs wing of the Tauheed-ul-Islam, who said that Tauheed-ul-Islam was mainly dealt with the dysfunctional Lashkar-i-Islam in Zakhakhel. The trucker Mangal Bagh was the chief of the government banned outfit Lashkar-i-Islam in Khyber (Hakim Khan, interview, 2020). In the tribal district Khyber there were two main kinds of peace militias known as Bazaar Zakhakhel peace Lashkar and Maidan Zakhakhel. This was 2010 when this Bazaar Zakhakhel peace militas was constituted to counter Mangal Bagh, a chief of the banned outfit Lashkar-i-Islam. The Zakhakhel peace Lashkar is also known as Tauheed-ul-Islam. The number of the volunteers of Bazaar Zakhakhel was about 250 while that of the Maidan Zakhakhel was around 1500. The chief commander of the Bazaar Zakhakhel peace lashkar was Munshi Khan while Bilal was its vice chief commander (Khan, interview, 2020).

\section{Bajaur}

Bajaur was the smallest agency of the erstwhile FATA and is now the smallest of the seven tribal districts of Khyber Pakhtunkhwa. Bajaur lies cheek by jowl with the Kunar province of the

\footnotetext{
${ }^{2}$ Qameez is a traditional lashkar
} 
neighbouring Afghanistan and has a great strategic location. Khar is the headquarters of this strategically important tribal district, it borders District Dir of the Khyber Pakhtunkhwa, linking it with the scenic Swat valley.

\section{Anti-Taliban militias in Salarzai}

The Anti-Taliban militias of the Salarzai of Bajaur were the most successful lashkars in the tribal belt. A former member of the National Assembly of the Pakistan Muslim League (PML-N) from Bajaur Shahab-u-Din Khan, alias Shahp-u-Din Khan, headed the peace lashkars of the Salarzai tribe in Pashat, Bajaur. The influential leaders of the peace lashakrs in Salarazi were known as Malik Manasab Khan and Malik Fazal Karim. These top leaders of the Salarzai peace lashkars were targeted in separate terrorist attacks. The Pakistani government conferred a medal of gallantry on Malik Manasab Khan.

In an interview at his Hujra in Bajaur, Israr Khan, a younger son of Shahab-u-Din Khan, told four sections of the Salarzai tribe known as Lar Amadak, Bar Amadak, Lar Sadin and Bar Sadin jointly constituted anti-Taliban militias. Key leaders of the four sections Lar Amadak, Bar Amadak, Lar Sadin and Bar Sadin concertedly reached a decision in a Jirga to form a peace militas (Israr Khan, interview, 2020). No specific criterion was adopted for the anti-Taliban militias of the Salarzai tribe as the tribesmen voluntarily joined the militias to defend their territory against the Taliban. Roughly the number of the fighters/volunteers of the anti-Taliban militias in Salarzai was round about 7,000, however, the number could even exceed as per the situation demands (Khan, interview, 2020).

\section{Counterinsurgency (COIN) Strategy}

The sole purpose of raising the anti-Taliban militias was to indulge the locals in the fight against militants. Gaining the favour of the locals and their involvement in the fight against the insurgents has been one of the most important dimensions of the counterinsurgency strategy. This is how the government created hurdles for the militants in enlisting or recruiting the tribals to their groups, particularly the jobless and frustrated youth, instead the government used these youths against the militants in providing secret intelligence to the military. As a counter-insurgency strategy, the antiTaliban militias were used mainly for three purposes viz self-defence, patrolling along with the military to control the areas where the security forces couldn't launch operations due to cultural or other reasons and provided them best intelligence."Military militias are also, however, traditional elements of counter-insurgency strategies, in many cases recruiting from the same communities as insurgents" (Salman Jago, 2006).

Insurgents in the erstwhile FATA used their consolidated endeavours to spread horror among the civilians. They frequently targeted the government infrastructures like roads, bridges, hospitals and schools to realize the tribals that the government is lacking the energy, resources or will to protect these installations. Attacking these government installations was also meant to challenge the writ of the government and to realize the tribals the weakness of the Government writ or control in the tribal belt.

Insurgency is usually deemed as systematic and integrated efforts of insurgents to use different tactics of guerrilla warfare, subversion and terrorism to harm the nation within. They try to influence the frustrated and hopeless population by showing them some rosy pictures of life associating them with challenging the writ or revolt against the government. They struggle to develop the civilians' beliefs that the government takes no interest to resolve their problems and the locals supporting the insurgents can ensure the emancipation of the civil population of the tyrannical rulers. The insurgents also apply their war propaganda, warfare tactics and intimidating tools to widen the gap in between the masses and the rulers (Mockaitis Thomas R, 1999).

The Counterinsurgency is considered as the different tactics or a coast-to-coast strategy to defeat the foes. This is a combination of different tools or various tactics like economical, sociological, psychological, paramilitary and military that are blended in it to wipe out an insurgency. Like insurgency, counterinsurgency is not a strategy, but a description of a strategic end-point (Paul B. Rich \& Isabelle Duyvesteyn, 2012).

\section{Monitoring System}

The government informally backed the raising of the anti-Taliban militias to serve its interest of combating the militants in the tribal belt. However, the government has not evolved any proper mechanism to monitor the peace militias' activities during or after their interest is served in the tribal 
belt. The lacking of any government strategy to monitor the Anti-Taliban militias' activities can tantamount their backlash with that of the Mujahideen in Afghanistan who deemed their role magnificent in defeating the Soviet Union troops in 1979 and thus declared themselves as the next legitimate rulers of the landlocked Afghanistan (Asad Durrani, interview, 2015).

Rustam Shah Mohmand, the former ambassador of Pakistan to Afghanistan, also believes that the rulers have not chalked out any strategy to tackle the peace militias and even any such policy is not in the offing. One mechanism that the government has evolved is setting up of cantonment in the area, where the insurgents were much vibrant, like the military has set up its cantonment in Bagh area of the Tirah Valley of the tribal district Khyber (Rustam Shah Momand, interview, 2020). Khadim Hussain, a political and security analyst, reveals as even no proper mechanism was evolved for the raising of peace militias and they were only left at the mercy of the security forces thus there was no monitoring system to supervise the activities of these peace militias. Later on, the government stopped supporting the Anti-Taliban and thus both the elders and fighters of the Aman Lashkars were exposed to the target killing in the tribal belt (Dr. Khadim Hussain, interview, 2020).

\section{Conclusion}

The government of Pakistan persuaded the tribal elders to form Lashkars against the militants. Though, the traditional Lashkars provided a foundation to the peace Lashkars, but both are different. The traditional Lashkars were usually formed and dispersed after they dealt with a dispute while the Aman lashkars enjoy a status of semi-permanent militias. Both the Traditional lashkars and the AntiTaliban militias are different in many ways. Like, all the members of a tribe can become a part of the Traditional Lashkars whenever there is a need for its formation. There were no specific criteria for the recruitment of the Traditional Lashkars. However, tough criteria were adopted for the recruitment of the Anti-Taliban militias. Every member of a tribe was not allowed to become a part of the AntiTaliban militias. The government of Pakistan used the Anti-Taliban militias as a counterinsurgency strategy in the tribal belt. The Anti-Taliban militias played much effective role in some areas like Salarzai of the tribal district Bajaur. Being well aware of the area, the members of the peace militias not only shared intelligence with the government forces, but also joined the routine patrolling of the Pakistani troops in the area. Though the formation of the private militias including the Anti-Taliban militias is contrary to the Constitution of 1973 of Pakistan, the government used these militias as an unannounced counterinsurgency strategy in the erstwhile FATA. As an announced strategy, the government of Pakistan has not adopted any proper monitoring system to monitor and control the activities of the Anti-Taliban militias; these militias can cause problems like lawlessness in the tribal districts of Khyber Pakhtunkhwa. As these militias have practiced power and wouldn't easily give it up that can cause problems in these tribal districts.

\section{References}

Asad Durrani. (2015, November 3). Local Militia as a Counterterrorism Strategy and Peacebuilding in the erstwhile FATA. Former ISI Chief, (Rahman Ullah, Interviewer) Islamabad.

Arshad Mohmand. (2020, March 09). Local Militia as a Counterterrorism Strategy and Peacebuilding in the erstwhile FATA. Voice of America Journalist in tribal district Mohmand, (Rahman Ullah, Interview) Mohmand.

Clegg, Well (2009) Irregular Forces in Counterinsurgency Warfare, Security Challenges, P. 1-2

Dr Ashraf Ali, (2020, February 08). Local Militia as a Counterterrorism Strategy and Peacebuilding in the erstwhile FATA. Ex-head of FATA Research Centre, (Rahman Ullah, Interview) Islamabad.

Dr. Khadim Hussain. (2020, January 05). Local Militia as a Counterterrorism Strategy and Peacebuilding in the erstwhile FATA. Director Bacha Khan Education Trust, (Rahman Ullah, Interviewer) Peshawar.

Francis, D. J. (2005). Civil Militia: Africa' s Intractable Security Menace? Retrieved September20, 2015, from https://www.ashgate.com/pdf/SamplePages/Civil_Militia_Intro.pdf

Hakim Khan. (2020, February 28). Local Militia as a Counterterrorism Strategy and Peacebuilding in the erstwhile FATA. Political affairs head of Tauheed-ul-Islam. (Rahman Ullah, Interviewer) Peshawar.

Israr Khan. (2020, April 20).Local Militia as a Counterterrorism Strategy and Peacebuilding in the erstwhile FATA. (Rahman Ullah, Interviewer) Pashat, Salarzai, Bajaur, Pakistan. 
Malik Yousaf. (2020, January 6).Local Militia as a Counterterrorism Strategy and Peacebuilding in the erstwhile FATA. (Rahmanullah, Interviewer) Inayat Kali, Bajaur, Pakistan.

Mockaitis Thomas R. (1999). From Counterinsurgency to Peace Enforcement: New Names for Old Games? Small Wars \&Insurgencies, 10 (2), 40-57.

Munir, M. (1999). The Constitution of the Islamic Republic of PakistanBeinga Commentary on The Constitution of Pakistan, 1973. Lahore: PLD.

Paul B. Rich \& Isabelle Duyvesteyn. (2012). Handbook of insurgency and counterinsurgency. London $\&$ New York: Routledge.

Rustam Shah Momand. (2020, December 7).Local Militia as a Counterterrorism Strategy and Peacebuilding in the erstwhile FATA. Former Ambassador, (Rahman Ullah, Interviewer)

Saboor, A. (1999, September). Qabaili Blog KaQayamWaqtKaTaqazaHai. The Daily Maidan, p. 12.

Saeedullah, K. (2020, January 10).Local Militia as a Counterterrorism Strategy and Peacebuilding in the erstwhile FATA Chief of peace committee Gurbaz, Safi Tehsil. (Rahmanullah, Interviewer) Gurbaz, Safi Tehsil, Momand, Pakistan.

Salman Jago. (2006). Militia Politics. The Formation and Organization of Irregular Armed Forces in Sudan (1985-2001) and Lebanon (1975-1991). Retrieved 09 22, 2015, from http://edoc.huberlin. de/dissertationen/salmon-jago-2006-07-18/PDF/salmon.pdf

Wali Khan Afridi. (2020, February 29). Local Militia as a Counterterrorism Strategy and Peacebuilding in the erstwhile FATA. Local Journalist, (Rahman Ullah, Interview) Khyber.

Zahid, H. (2007). Frontline Pakistan: the struggle with militant Islam. London: I.B.Tauris\& Co Ltd, 2007. 